\title{
STUDI PENGGUNAAN SEMIKONVERTER AC-DC UNTUK MENGATUR KECEPATAN MOTOR DC
}

\author{
Hadiyansyah $^{1}$, Atmam ${ }^{2}$, David Setiawan ${ }^{3}$ \\ 1,2,3 Program Studi Teknik Elektro, Fakultas Teknik, Universitas Lancang Kuning Pekanbaru. \\ Jl. Yos Sudarso Rumbai, Pekanbaru, Telp. (0761) 52324 \\ Email : hadiyansyah@ft.unilak.ac.id, atmam@unilak.ac.id, dsetia@unilak.ac.id
}

\begin{abstract}
ABSTRAK
Sumber tegangan arus searah memiliki peranan penting dalam pengoperasian peralatan elektronik yang berfungsi sebagai catu daya. Catu daya tersebut berupa sumber bolak-balik atau yang dikenal dengan AC (Alternating Current). Kemudian dalam hal ini sumber AC tersebut disearahkan dengan komponen rectifier. Komponen rectifier dibagi menjadi dua jenis di antaranya penyearah tidak terkontrol dan penyearah terkontrol, untuk mendapatkan tegangan output yang berubah-ubah dari penyearah tidak terkontrol dengan merubah tegangan sumber AC masukan menggunakan AC Voltage Regulator, sedangkan menggunakan penyearah terkontrol untuk mendapatkan tegangan DC yang dapat dirubah-rubah cukup dengan mengontrol sudut penyalaan $\alpha$ dalam keadaan tegangan masukan konstan. Dengan menggunakan motor DC magnet permanen yang mana flux magnet dalam keadaan konstan, untuk mengatur kecepatan dari motor DC magnet permanen yaitu dengan mengatur tegangan terminal, untuk mengatur tegangan terminal dari motor DC tersebut menggunakan rangkaian semikonverter dengan merubah sudut $\alpha$ untuk mendapatkan putaran yang diinginkan. Hasil yang diperoleh dari sudut $\alpha 105^{\circ}$ dengan Vs konstan, $V_{\text {dc }}$ bernilai 71,2367 Volt, $V_{\text {rms }}$ 121,57 Volt dan memiliki arus sebesar 0,03 Amp, semakin besar sudut penyalaan semakin kecil arus output yang diperoleh. Ketika motor DC dibebani, arus naik menjadi 0,047 Amp, sehingga kecepatan motor menjadi 3436,13 rpm.
\end{abstract}

Kata kunci : Semikonverter, kontrol, kecepatan dan motor DC

\section{ABSTRACT}

Direct current voltage sources play an important role in the operation of electronic equipment that functions as a power supply. The power supply is an alternating source or alternating current. Then, in this case the AC source is aligned with the rectifier component. Rectifier components are divided into two types including uncontrolled rectifiers and controlled rectifiers. To get an output voltage that changes from an uncontrolled rectifier is to change the input AC source voltage using AC Voltage Regulator. Meanwhile, by using a controlled rectifier, to obtain a changed DC voltage - change is enough to control the ignition angle a in the state of constant inlet voltage. By using a permanent magnet DC motor where magnetic flux is constant, to regulate the speed of a permanent magnet DC motor is to set the terminal voltage of the DC motor using a semi converter circuit and change the angle a to get the desired rotation. The results obtained from the angle a 1050 with $V_{S}$ constant, the $V_{D C}$ result is 71,2367 Volt, the $V_{r m s}$ is 121,57 Volt and has a current value of 0.03 Amp. The greater the ignition angle is the smaller the output current is obtained. When the DC motor is loaded, the current rises to 0.047 Amp, so the motor speed becomes $3436.13 \mathrm{rpm}$.

Keywords: Semiconverter, control, speed and DC motor

\section{PENDAHULUAN}

Sumber tegangan arus searah memiliki peranan penting dalam pengoperasian peralatan elektronik yang berfungsi sebagai catu daya. Catu daya tersebut berupa sumber bolak-balik atau yang dikenal dengan AC (Alternating Current). Kemudian dalam hal ini sumber AC tersebut disearahkan dengan komponen rectifier.

Komponen rectifier dibagi menjadi dua jenis diantaranya penyearah tidak terkontrol dan penyearah terkontrol, untuk mendapatkan tegangan output yang berubah-ubah dari penyearah tidak terkontrol kita harus merubah tegangan sumber $\mathrm{AC}$ masukan menggunakan AC Voltage Regulator sedangkan menggunakan penyearah terkontrol untuk mendapat tegangan DC yang dapat diubah-ubah cukup dengan mengontrol sudut penyalaan $\alpha$ dalam keadaan tegangan masukan konstan.

Rectifier terkontrol atau sering disebut rangkaian konverter AC-DC yang menggunakan komponen thyristor dan dioda, sedangkan tegangan keluaran dari penyearah thyristor dapat diubah-ubah dengan mengatur sudut penyalaan pada gerbang thyristor, caranya dengan memberi pulsa pada gerbang yang dapat diatur dari sudut $\alpha=0^{\circ}$ sampai 
sudut $\alpha=180^{\circ}$. Rangkaian konverter dapat diklasifikasikan menjadi dua macam tergantung dari sumber masukannya salah satunya konverter satu phasa, penyearah terkontrol dapat pula dibagi menjadi beberapa jenis salah satunya penyearah setengah terkontrol, penyearah setengah terkontrol dapat digunakan untuk pengaturan motor DC.

Dalam penelitian ini menggunakan motor DC magnet permanen yang mana fluks magnetnya dalam keadaan tetap. Untuk mengatur kecepatan dari motor DC magnet permanen dilakukan dengan mengatur tegangan terminal $\left(\mathrm{V}_{\mathrm{t}}\right)$ dimana mengatur tegangan terminal $\left(\mathrm{V}_{\mathrm{t}}\right)$ dari motor $\mathrm{DC}$ tersebut dapat menggunakan semikonverter dengan cara mengubah sudut penyalaan Thyristor sehingga didapatkan putaran yang diinginkan.

\section{METODE PENELITIAN}

\section{Pembuatan Blok Diagram}

Diagram Blok Rangkaian Semikonverter ACDC menggunakan IC TCA785 sebagai trigger dan Arduino sebagai control feedback dan motor sebagai beban seperti pada Gambar 1.

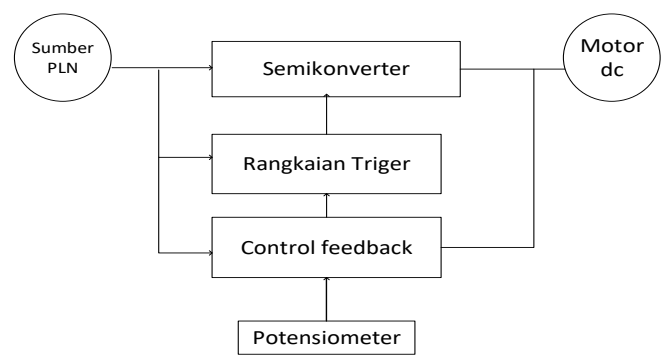

Gambar 1. Blok Diagram Semikonverter

\section{Rangkaian Trigger}

Rangkaian trigger merupakan rangkaian yang menghasilkan pulsa untuk mengontrol gerbang thyristor sehingga thyristor dapat dikontrol dari sudut penyalaan thyristor $\alpha=0^{\circ}$ sampai dengan sudut $\alpha=$ $180^{\circ}$, rangkaian trigger ini terdiri dari komponen utama yaitu IC TCA785 dan komponen pendukung lainnya. Blok dari rangkaian trigger seperti pada Gambar 2 Blok Rangkaian Trigger dan Gambar 3 Rangkaian Trigger.

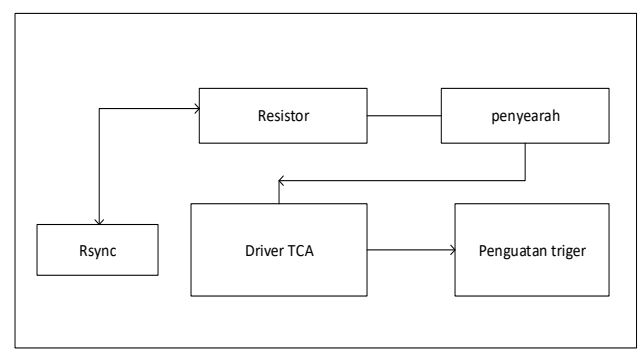

Gambar 2. Blok Rangkaian Trigger

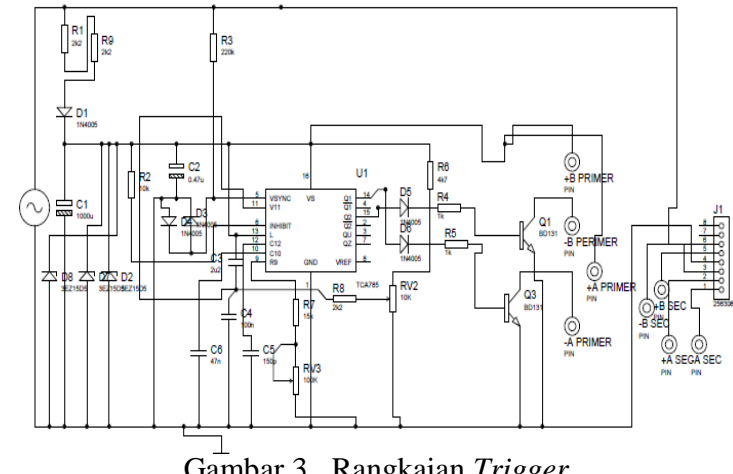

Gambar 3. Rangkaian Trigger

\section{Rangkaian Semikonverter}

Rangkaian penyearah Semikonverter terdiri dari dua diode dan dua thyristor, kemudian thyristor tersebut dikontrol menggunakan rangkaian trigger untuk mendapatkan tegangan output yang berubahubah untuk, rangkaian semikonverter seperti pada Gambar 4.

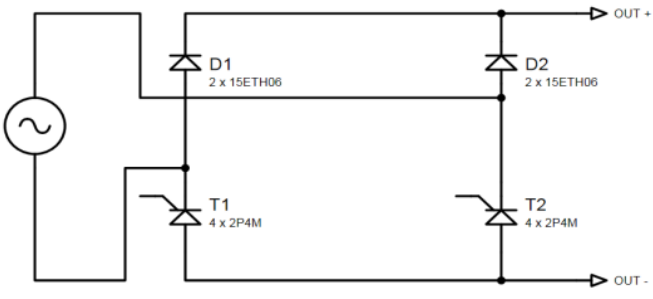

Gambar 4. Rangkaian Semikonverter

\section{Kontrol control Feedback}

Rangkaian ini berfungsi untuk mengontrol tegangan dari output semikonverter keadaan tetap, meskipun tegangan input berubah-ubah rangkaian kontrol ini menggunakan Arduino nano sebagai pengontrolan IC trigger untuk mengubah sudut penyalaan rangkaian semikonverter. Kemudian output dari rangkaian semikonverter terhubung dengan sensor arus dan sensor tegangan, kemudian sensor tegangan mengirim sinyal ke Arduino untuk memerintah rangkaian menaikkan atau menurunkan tegangan semikonverter dan sensor arus bekerja sebagai proteksi arus lebih dari output semikonverter. Gambar 5 berikut blok kontrol feedback dan Gambar 6 Rangkaian control feedback.

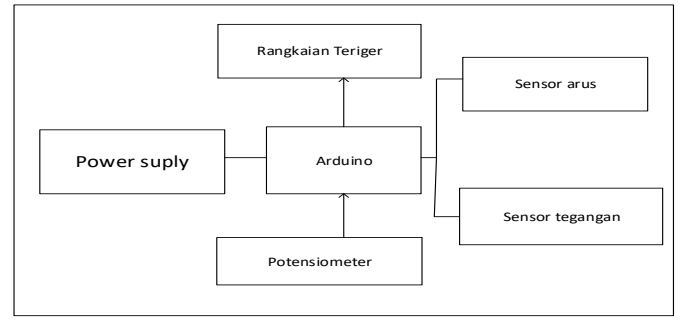

Gambar 5. Blok Rangkaian Control Feedback 


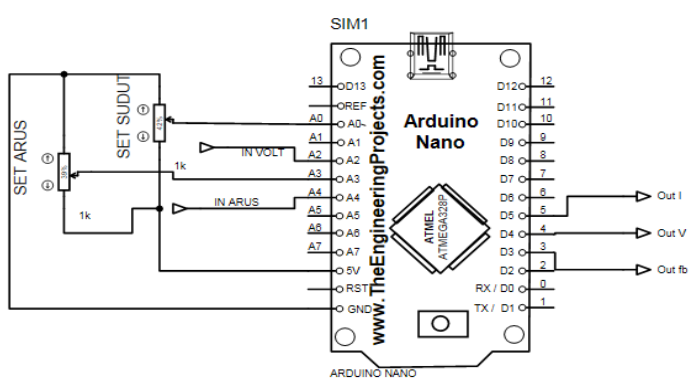

Gambar 6. Rangkaian Control feedback

\section{Sensor Arus ACS712}

Prinsip kerja Sensor ini untuk membaca nilai arus beban dari rangkaian semikonverter, supaya tidak melebihi arus kemampuan komponen penguatan semikonverter itu sendiri, untuk rangkaian sensor Arus seperti pada Gambar 7.

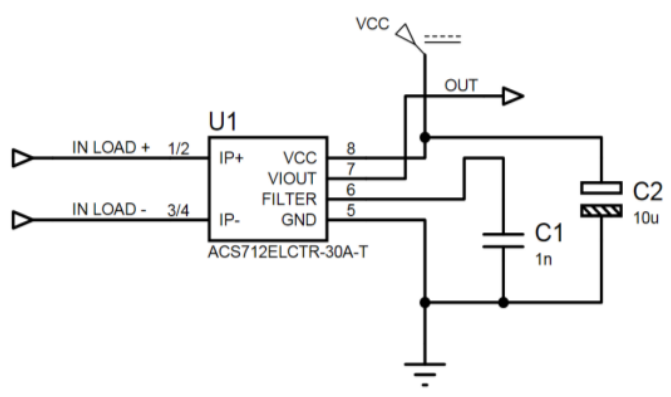

Gambar 7. Rangkaian Sensor Arus

\section{Sensor Tegangan}

Sensor tegangan ini digunakan untuk membaca nilai tegangan yang di keluarkan suatu rangkaian yang berupa sinyal analog kemudian dijadikan sinyal digital oleh perangkat arduino melalui Pin Analog, sensor tegangan ini tidak boleh melebihi tegangan arduino yaitu \pm 5 Volt seperti pada Gambar 8.

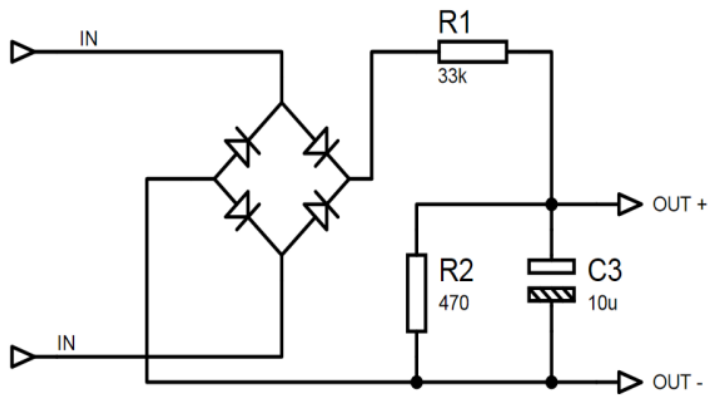

Gambar 8. Rangkaian Sensor Tegangan

\section{Semikonverter}

Rangkaian semikonverter merupakan rangkaian penyearah yang terkontrol dengan keluaran arus dan tegangan yang diatur dalam pengontrolan semikonverter menggunakan thyristor dan dioda, sedangkan keluaran dari penyearah thyristor dapat diubah besarnya dengan mengatur sudut penyalaan pada gerbang thyristor. Rangkaian semikonverter terdiri dari 2 buah dioda dan 2 buah thyristor.

Cara pengaturannya adalah dengan memberi pulsa pada gerbang thyristor, dimana pulsa tersebut dapat digeser atau diatur dari sudut $\alpha 0^{\circ}$ sampai $180^{\circ}$. Apabila pada gerbang thyristor diberi pulsa atau arus penyalaan, maka pada saat siklus positif, thyristor akan menghantar (on) dan pada siklus negatif thyristor tidak dapat menghantar (off).

Masukan tegangan AC akan membuat thyristor bekerja sebagai saklar on - off secara terus menerus sampai masukan sinyal AC dihentikan. Agar thyristor dapat menghantar secara kontinyu maka diperlukan pulsa atau arus penyalaan secara terus menerus. Sumber tegangan AC yang masuk pada rangkaian semikonverter dapat berupa sumber tegangan satu phasa atau tiga phasa sedangkan keluaran semikonverter merupakan tegangan DC seperti pada Gambar 9 [1].

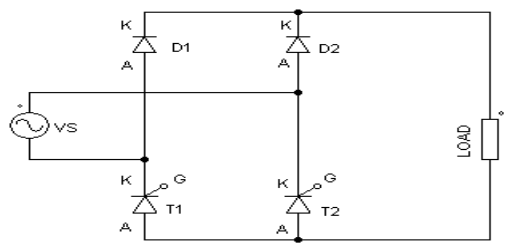

Gambar 9. Rangkaian Semikonverter

Tegangan $\mathrm{V}_{\text {avg }}$ semikonverter dapat dihitung [2]:

$$
V_{d c}=\frac{V_{m}}{\pi}[1+\cos \alpha]
$$

Tegangan $V_{r m s}$ Semikonverter dapat dihitung menggunakan persamaan 2 [2]

$V_{r m s}=\frac{V_{m}}{\sqrt{2}}\left[\frac{1}{\pi}\left\{(\pi-\alpha)+\frac{1}{2} \sin 2 \alpha\right\}\right]^{1 / 2}$

Selanjutnya tegangan maksimum $\left(\mathrm{V}_{\mathrm{m}}\right)$ dapat dihitung menggunakan persamaan 3 [2]

$$
V_{m}=V_{s} \times \sqrt{2}
$$

Tegangan $\mathrm{V}_{\text {avg }}$ semikonverter dapat dihitung [2]:

$$
V_{d c}=\frac{V_{m}}{\pi}[1+\cos \alpha]
$$

Tegangan $V_{r m s}$ Semikonverter dapat dihitung menggunakan persamaan 5 [2] :

$$
V_{r m s}=\frac{V_{m}}{\sqrt{2}}\left[\frac{1}{\pi}\left\{(\pi-\alpha)+\frac{1}{2} \sin 2 \alpha\right\}\right]^{1 / 2}
$$




\section{Rangkaian Penyearah}

Penyearah satu phasa adalah rangkaian dioda yang menyearahkan sumber tegangan AC satu phasa menjadi tegangan DC. Ada beberapa penyearah satu phasa, tetapi yang sering digunakan adalah penyearah gelombang penuh sistem jembatan. Penyearah jembatan ini mempunyai keluaran DC yang cukup baik sehingga memperkecil harmonisa dan menghasilkan nilai tegangan rata-rata yang maksimal. Rangkaian penyearah gelombang penuh satu phasa ditunjukkan seperti pada Gambar 10 [3].

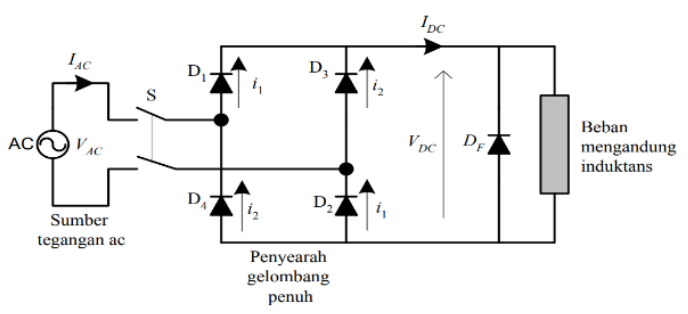

Gambar 10. Rangkaian Gelombang Penuh

Penyearah gelombang penuh dapat disusun oleh empat buah dioda yang terhubung sebagai jembatan. Bila diberikan input tegangan jala-jala $V s(t)=V_{m}$ $\sin \omega$ maka setengah perioda yaitu gelombang positif ( $0 \leq \omega \mathrm{t} \leq \pi$ ) tegangan akan diberikan ke beban oleh pasangan dioda $D_{1}$ dan $D_{2}$, selanjutnya untuk setengah perioda gelombang negatif $(\pi \leq \omega t \leq 2 \pi)$ tegangan diberikan oleh pasangan dioda $\mathrm{D}_{3}$ dan $\mathrm{D}_{4}$. Bentuk tegangan keluaran akibat input tegangan sinusoida ditunjukkan seperti pada Gambar 11.

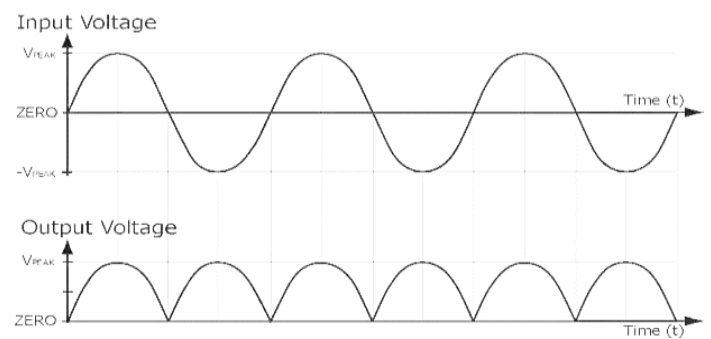

Gambar 11. Gelombang Tegangan Output Penyearah

\section{Thyristor}

Sebagai saklar thyristor akan aktif (on) jika tegangan pada anoda lebih positif dari pada tegangan pada katoda dan pada terminal gate dialirkan arus pulsa positif. Kondisi (on) Thyristor ini ditentukan oleh besar arus pulsa positif pada gate dan SCR akan tetap (on) meskipun arus pulsa pada gate diputus. SCR akan putus (off) dengan cara membuat tegangan pada anoda sama dengan katoda. Proses pengaliran arus listrik pada terminal gate ini disebut penyulutan/pemicu (triggering), sedangkan proses pemutusan (off) dari kondisi (on) ini disebut komutasi [4].

\section{IC TCA785}

IC TCA 785 merupakan produk dari siemen semikonduktor group yang dibuat untuk menghasilkan pulsa pemicu (trigger pulse) untuk mengontrol phasa pada SCR, triac, dan transistor, antara sudut $\alpha=0^{\circ}$ hingga $\alpha=180^{\circ}$ derajat pada sumber tegangan AC. IC TCA785 memerlukan sumber tegangan antara 8 Volt hingga 18 Volt, frekuensi kerja $10 \mathrm{~Hz}$ hingga $500 \mathrm{~Hz}$, serta temperatur kerja antara $25^{\circ} \mathrm{C}$ hingga $85^{\circ} \mathrm{C}$. Sinkronisasi sinyal dibutuhkan dengan menggunakan resistansi tingkat tinggi dari line tegangan (Vs). Gambar 12 menunjukkan bentuk fisik dari IC TCA 785[5]

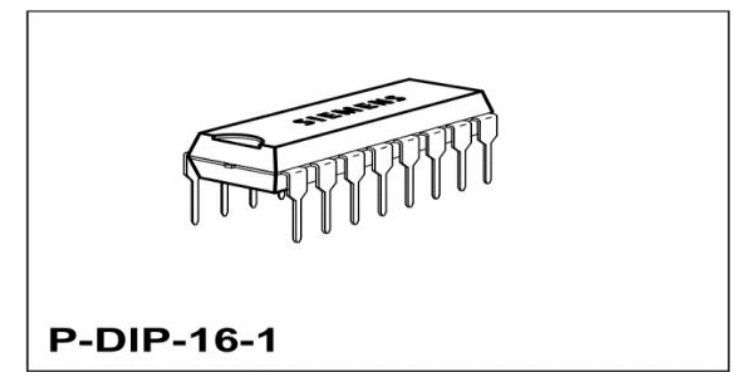

Gambar 12. IC TCA 785[5]

IC ini dapat diaplikasikan pada kontrol tegangan AC terkontrol (converter) satu phasa dan tiga phasa, dan kontrol tegangan DC terkontrol (DC chopper). IC ini memiliki kaki (pin) sejumlah 16. Gambar 13 menunjukkan pin konfigurasi dari sebuah IC TCA785.

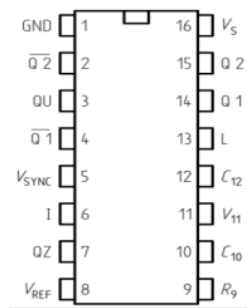

Gambar 13. Pin Konfigurasi

Prinsip kerja IC TCA785 adalah sinyal sinkronisasi dari tegangan sumber dihubungkan pada kaki nomor 5 ( $\left.\mathrm{V}_{\text {SYNC }}\right)$ melalui resistor berhambatan tinggi. Zero detector akan menentukan letak titik nol dan disimpan kedalam memori sinkron. Detector ini kemudian akan mengendalikan gelombang tegangan yang sesuai dengan frekuensi sumber tegangan. Kapasitor $\mathrm{C}_{10}$ dan $\mathrm{R}_{9}$ akan menentukan kemiringan dari bentuk gelombang yang dihasilkan. Gelombang ini kemudian dibandingkan dengan tegangan referensi $\mathrm{V}_{11}$ oleh comparator (pembanding). Sinyal output dari comparator ini kemudian akan diteruskan ke rangkaian logika. Bila tegangan referensi pada kaki $11\left(\mathrm{~V}_{11}\right)$ pada posisi terendah maka sudut penyulutan akan menunjukkan $\alpha=0$ derajat. Sehingga untuk mengatur sudut pemicu dapat 
dilakukan dengan mengatur besar tegangan yang dikirimkan ke pin $11\left(\mathrm{~V}_{11}\right)$ seperti pada Gambar 14 [6].

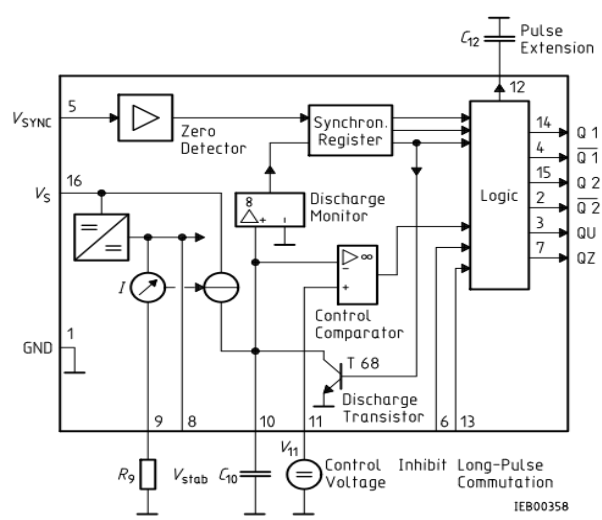

Gambar 14. Blok Diagram Prinsip Kerja IC TCA785[7]

Bentuk gelombang output dari IC TCA785 seperti pada Gambar 15.

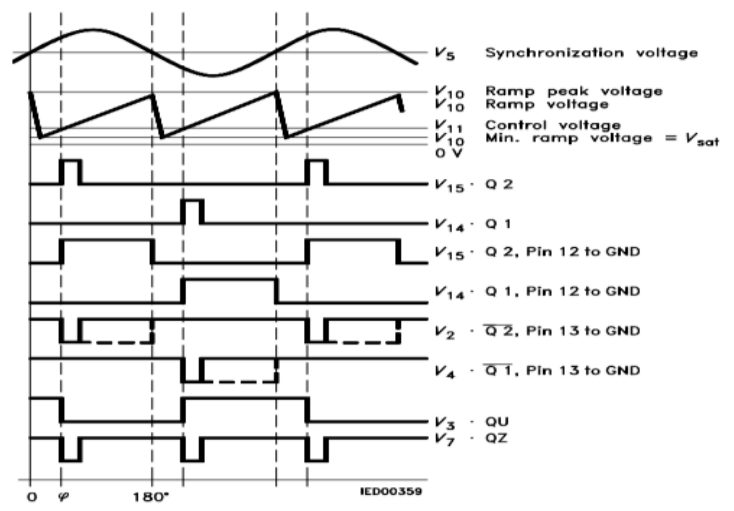

Gambar 15. Diagram Pulsa [7]

\section{Motor Arus searah}

Pada prinsipnya mesin listrik dapat berlaku sebagai motor maupun sebagai generator. Perbedaannya terletak pada konversi dayanya, generator adalah suatu mesin listrik yang mengubah daya masuk mekanik menjadi daya keluar listrik, sedangkan sebaliknya motor mengubah daya masuk listrik menjadi daya keluar mekanik [8].

Motor DC digunakan pada penggunaan khusus dimana diperlukan penyalaan torque yang tinggi atau percepatan yang tetap untuk kisaran kecepatan yang luas, berikut memperlihatkan sebuah motor DC yang memiliki tiga komponen utama :

\section{Kutub medan}

Secara sederhana digambar secara instraksi menyebabkan putaran pada motor DC, motor DC memiliki kutub medan yang stasioner dan dinamo yang menggerakan bearing pada ruang diantara kutub medan.

\section{Dinamo}

Bila arus masuk menuju dinamo maka arus ini akan menjadi elektromagnetik, dinamo berbentuk silinder, dihubungkan AS penggerak untuk menggerakan beban, untuk kasus motor DC kecil, dinamo berputar dalam medan magnet yang dibentuk oleh kutub-kutub, sampai kutub utara dan selatan dan setelah magnet berganti lokasi, jika hal ini terjadi, arus berbalik untuk merubah kutub-kutub utara dan selatan.

\section{Commutator}

Commutator ini terutama di temukan dalam motor DC. Kegunaannya adalah untuk membalikkan arah arus listrik dalam dinamo, commutator juga membantu dalam arus dinamo dan sumber daya[9]

\section{Rangkaian Ekivalen}

Rangkaian ekivalen dari sebuah motor DC magnet permanen dapat ditunjukan seperti pada Gambar 16 [7].

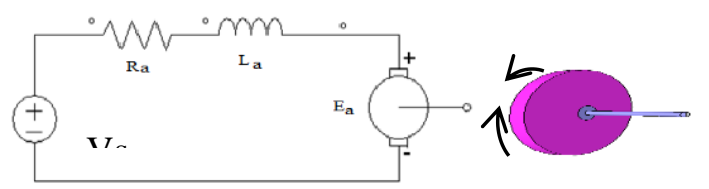

Gambar 16. Ekivalen Motor DC

Keterangan :

$\mathrm{R}_{\mathrm{a}} \quad=$ Tahanan jangkar $(\mathrm{Ohm})$

$\mathrm{L}_{\mathrm{a}} \quad=$ Induktansi $(\mathrm{H})$

$\mathrm{Vs}(\mathrm{t}) \quad=$ Tegangan Terminal (Volt $)$

Motor arus searah dari rumus umum motor arus searah untuk menentukan titik dimana dapat dilakukan pengaturan kecepatan adalah sebagai berikut [8] :

Untuk tegangan induksi berlaku hubungan [8] :

$E_{a}=C . N . \Phi$

Atau :

$E_{a} \quad=V_{t} \cdot I_{a} \cdot R_{a}$

Persamaan untuk mencari kecepatan motor [8] :

$$
N=\frac{E_{a}}{{ }_{C} \Phi}
$$

Keterangan :

$$
\begin{array}{ll}
E_{a} & =\text { Gaya gerak listrik (Volt) } \\
\Phi & =\text { Fluks Magnet }(\mathrm{Wb}) \\
C & =\text { Konstanta } \\
\mathrm{V}_{\mathrm{t}} & =\text { Tegangan Terminal (Volt) } \\
\mathrm{I}_{\mathrm{a}} & =\text { Arus Jangkar (Amper) } \\
\mathrm{R}_{\mathrm{a}} & =\text { Tahanan Jangkar (Ohm ) }
\end{array}
$$




\section{Sejarah Arduino}

Arduino pertama kali diperkenalkan pada tahun 2005. Tim awal yang memprakarsai Arduino adalah Massimo Banzi, David Cuartieles, Tom lgoe, Gianluca Martino, and David Mellis. Nama Arduino berasal dari nama kedai minum di Ivrea, Italia, yang menjadi tempat mereka berkumpul dalam membahas proyek Arduino.

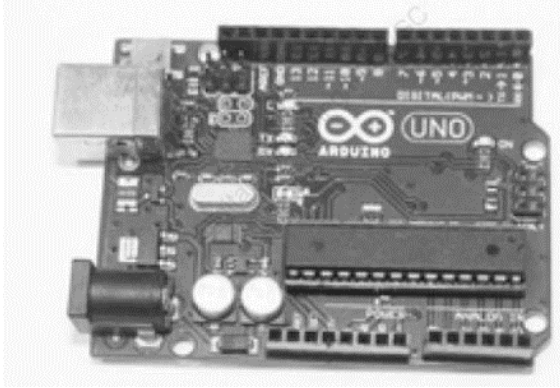

Gambar 17. Papan Arduino

Papan Arduino sendiri bermacam-macam. Salah satu yang populer adalah Arduino Uno seperti yang ditunjukkan pada Gambar 17. Papan ini mengandung sebuah mikrokontroller buatan Atmel yang menjadi pusat pengendali perangkat keras dan sejumlah pin untuk kepentingan operasi masukan (input) dan keluaran (output). Catu daya dapat diperoleh dari PC melalui kabel USB. Kabel ini juga sekaligus menjadi media untuk berkomunikasi antara Arduino dan PC [10].

\section{Sensor Arus ACS712}

ACS712 adalah Hall Effect current sensor. Hall effect allegro ACS712 merupakan sensor yang presisi sebagai sensor arus AC atau DC dalam pembacaan arus didalam dunia industri, otomotif, komersil dan sistem-sistem komunikasi. Pada umumnya aplikasi sensor ini biasanya digunakan untuk mengontrol motor, deteksi beban listrik, switched-mode power supply dan proteksi beban berlebih [11]. Blok dari IC seperti pada Gambar 18 dan pin IC seperti pada Gambar 19.

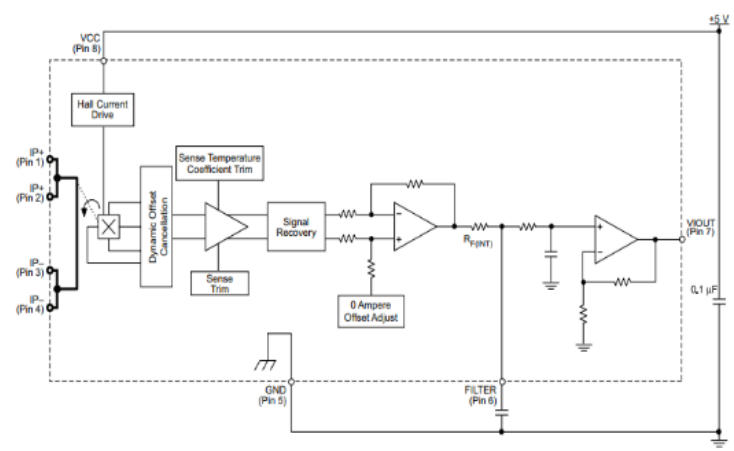

Gambar 18. Block IC ACS712

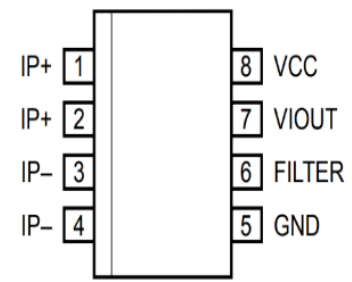

Gambar 19. Pin IC ACS712

Keterangan fungsi pin IC ACS712 seperti pada Tabel

Tabel 1 PIN ACS712

\begin{tabular}{lll} 
PIN & Nama PIN & Diskripsi PIN \\
\hline 1 dan 2 & IP+ & Terminal Internal sensor arus \\
3 dan 4 & IP- & Terminal internl sensor arus \\
5 & GND & Terminal Ground \\
6 & FILTER & Terminal External kapasitor \\
7 & VOUT & Analog Output Signal \\
8 & VCC & Power Supply Internal \\
\hline
\end{tabular}

\section{Hukum 1 Kirchhoff}

Jumlah kuat arus listrik yang masuk kesuatu titik simpul sama dengan jumlah kuat arus yang keluar dari titik simpul tersebut

$$
\sum I \text { masuk }=\sum I \text { keluar }
$$

Hukum 1 Kirchoff pada hubungan seri dan paralel komponen-komponen listrik (misal : lampu pijar) serta rangkaian penggantinya resistor [9]seperti pada Gambar 20 berikut :

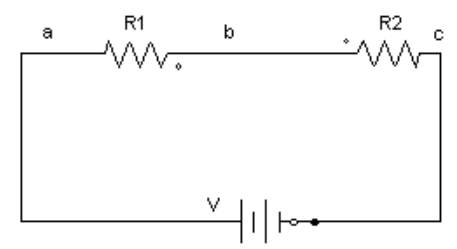

Gambar 20. Rangkaian Hubungan Seri

Untuk mencari tegangan $\mathrm{R}_{1}$ maka :

$\mathrm{V}_{\mathrm{ab}}=\frac{R_{1}}{R_{1}+R_{2}} \times V$

\section{Rangkaian RL}

Rangkain RL adalah rangkaian yang terdiri dari resistor dan induktor. Rangkain tersebut mengubah arus menjadi medan magnet yang 
disimpan dalam induktor. Rangkaian RL seri yang sederhana seperti pada Gambar 21 [7].

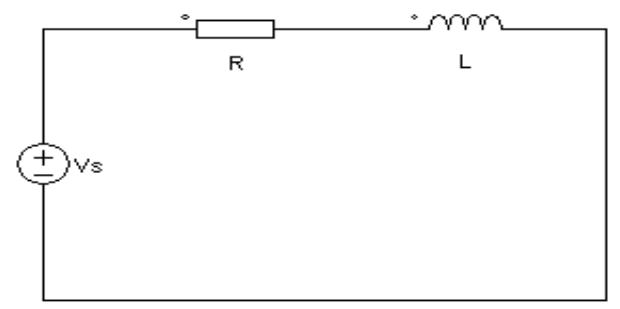

Gambar 21. Rangkaian RL

Arus yang berubah-ubah terhadap waktu sebagai $i(\mathrm{t})$, dan misalkan nilai $i(\mathrm{t})$ pada $\mathrm{t}=0$ dinyatakan sebagai $\mathrm{I}_{0}$, maka diperoleh :

$$
V_{r}+V_{L}=R i+L \frac{d i}{d t}=0
$$

\section{HASIL DAN PEMBAHASAN}

\section{Sudut $\alpha$ dengan oscilloscope}

Perhitungan dilakukan dengan cara melihat DutyCycle dari oscilloscope seperti pada Gambar 22.

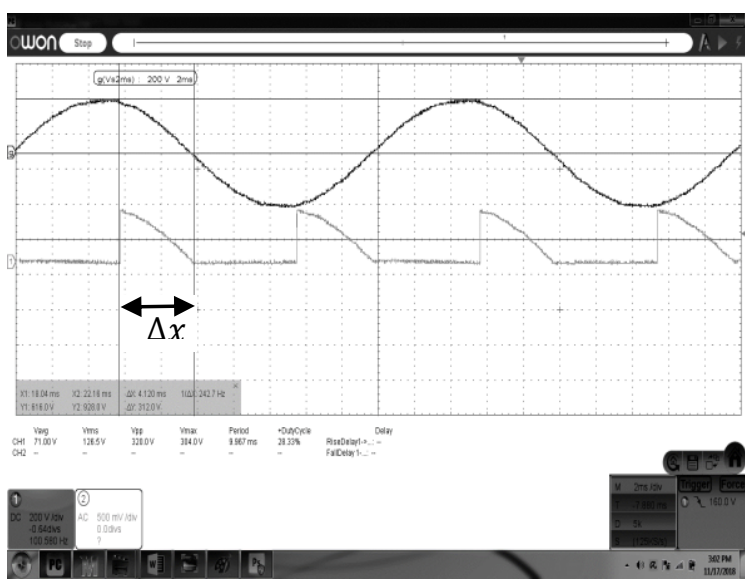

Gambar 22. Sudut $\alpha 105^{\circ}$

$$
\begin{gathered}
\text { DutyCycle }=\Delta x \times \text { Perioda } \\
\begin{array}{c}
\text { DutyCycle }=4,120 \times 10 \\
=41,2 \\
\alpha=\frac{180(100-\text { Dutycycle })}{100}
\end{array}
\end{gathered}
$$

Tegangan dan arus Rata-rata $\left(V_{\text {avg }}\right)$ beban resistansi

Hasil keluaran tegangan rata-rata dari rangkaian semikonverter dengan sudut yang telah ditentukan yaitu sebesar $105^{\circ}, 110^{\circ}$ dan $115^{\circ}$ pada Tabel 2
Tabel 2. Tegangan Rata-Rata Dan Arus Rata-Rata

\begin{tabular}{ccccc}
\hline No & Sudut $\alpha$ & $\begin{array}{c}\mathrm{V}_{\mathrm{s}} \\
(\text { Volt })\end{array}$ & $\begin{array}{c}\mathrm{V}_{\mathrm{dc}} \\
(\text { Volt })\end{array}$ & $\begin{array}{c}\mathrm{I} \\
\text { (Amper) }\end{array}$ \\
\hline 1 & $105^{\circ}$ & 213,4 & 71,2367 & 0,03238 \\
2 & $110^{\circ}$ & 213,2 & 63,1808 & 0,02872 \\
3 & $115^{\circ}$ & 212,8 & 55,3376 & 0,02515 \\
4 & $120^{\circ}$ & 210,5 & 47,4032 & 0,02155 \\
5 & $125^{\circ}$ & 210,5 & 40,4277 & 0,01838 \\
6 & $130^{\circ}$ & 214,4 & 34,4935 & 0,01568 \\
7 & $135^{\circ}$ & 213,4 & 28,1507 & 0,0128 \\
8 & $140^{\circ}$ & 212 & 22,3385 & 0,01015 \\
9 & $145^{\circ}$ & 210 & 17,1048 & 0,00777 \\
10 & $150^{\circ}$ & 212,5 & 12,8223 & 0,00583 \\
11 & $155^{\circ}$ & 214,4 & 9,04719 & 0,00411 \\
12 & $160^{\circ}$ & 214,3 & 5,82074 & 0,00265 \\
\hline
\end{tabular}

Dari data Tabel 2 maka dapat dibuat grafik perbandingan antara sudut penyalaan terhadap tegangan rata rata $\left(\mathrm{V}_{\mathrm{avg}}\right)$ seperti pada Gambar 23.

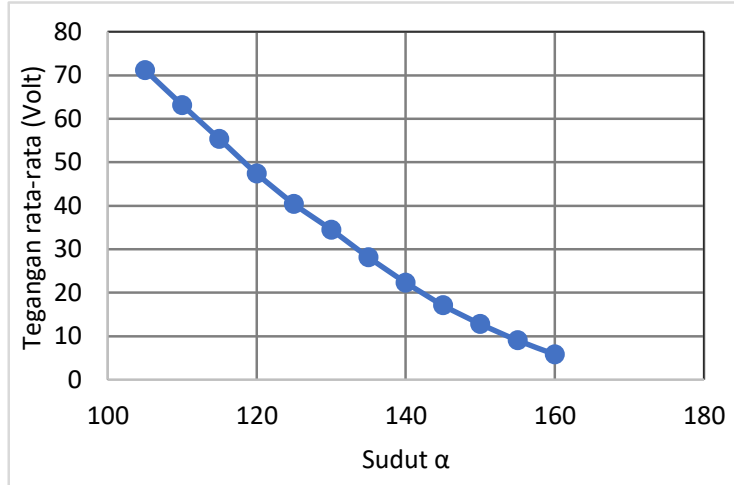

Gambar 23. Grafik Tegangan Rata-Rata $\left(V_{a v g}\right)$ Terhadap Perubahan Sudut $\alpha$

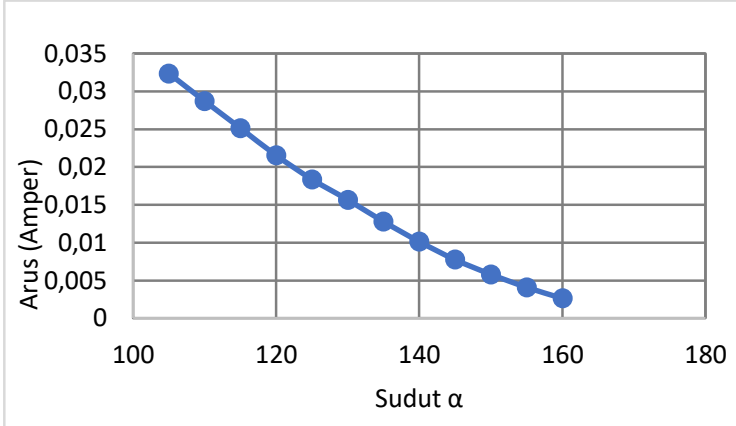

Gambar 24. Grafik Arus Rata-Rata Terhadap Sudut $\alpha$

Data beban RL dari sudut yang telah di tentukan sebesar $105^{\circ}, 110^{\circ}$ dan $115^{\circ}$ pada Tabel 3 . 
Tabel 3. Hasil Perhitungan Beban RL

\begin{tabular}{ccc}
\hline No & Sudut $\alpha$ & $\begin{array}{c}\mathrm{V}_{\mathrm{dc}} \\
(\text { Volt })\end{array}$ \\
\hline 1 & $105^{\circ}$ & 214 \\
2 & $110^{\circ}$ & 196,13 \\
3 & $115^{\circ}$ & 185,4 \\
4 & $120^{\circ}$ & 167,6 \\
5 & $125^{\circ}$ & 157,7 \\
6 & $130^{\circ}$ & 132,6 \\
7 & $135^{\circ}$ & 108,2 \\
8 & $140^{\circ}$ & 88,6 \\
9 & $145^{\circ}$ & 57,9 \\
10 & $150^{\circ}$ & 41,5 \\
11 & $155^{\circ}$ & 23,7 \\
12 & $160^{\circ}$ & 6,32 \\
\hline
\end{tabular}

Dari data pada Tabel 2 dan Tabel 3 dapat dibuat grafik perbandingan Sudut $\alpha$ Terhadap tegangan beban motor dan beban resistansi seperti pada Gambar 25.

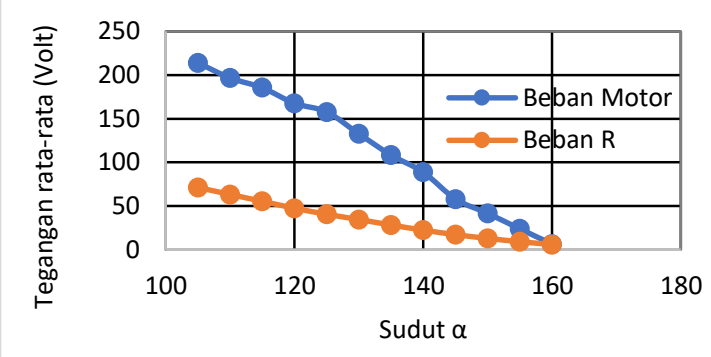

Gambar 25. Grafik Sudut terhadap tegangan

Data kecepatan motor dari sudut yang telah di tentukan sebesar $105^{\circ}, 110^{\circ}$ dan $115^{\circ}$ pada Tabel 4

Tabel 4. Hasil Perhitungan Kecepatan Motor

\begin{tabular}{ccccc}
\hline No & $\begin{array}{c}\text { Sudut } \\
\alpha\end{array}$ & $\begin{array}{c}\mathrm{V}_{\mathrm{dc}} \\
(\text { Volt })\end{array}$ & $\begin{array}{c}\mathrm{I} \\
(\text { Amper })\end{array}$ & $\begin{array}{c}\mathrm{N} \\
(\mathrm{rpm})\end{array}$ \\
\hline 1 & $105^{\circ}$ & 214 & 0,04762 & 3436,13 \\
2 & $110^{\circ}$ & 196,7 & 0,04675 & 3140,92 \\
3 & $115^{\circ}$ & 185,4 & 0,04588 & 2967,65 \\
4 & $120^{\circ}$ & 167,6 & 0,04495 & 2675,92 \\
5 & $125^{\circ}$ & 157,7 & 0,03313 & 2536,16 \\
6 & $130^{\circ}$ & 132,6 & 0,03023 & 2127,76 \\
7 & $135^{\circ}$ & 108,2 & 0,02763 & 1730,31 \\
8 & $140^{\circ}$ & 88,6 & 0,02609 & 1409,95 \\
9 & $145^{\circ}$ & 57,9 & 0,02436 & 906,806 \\
10 & $150^{\circ}$ & 41,5 & 0,02246 & 639,973 \\
11 & $155^{\circ}$ & 23,7 & 0,02003 & 351,095 \\
12 & $160^{\circ}$ & 6,32 & 0,01887 & 66,6127 \\
\hline
\end{tabular}

Dari Data pada tabel 4 dapat dibuat grafik perbandingan antara tegangan rata-rata $\left(\mathrm{V}_{\mathrm{avg}}\right)$ terhadap putaran motor DC seperti pada Gambar 25

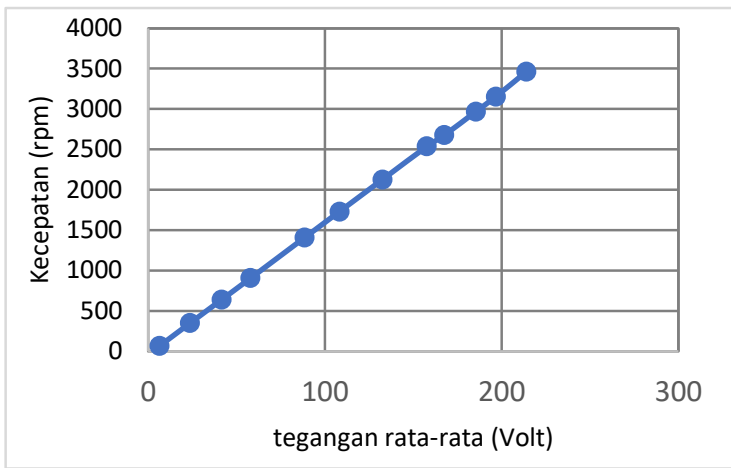

Gambar 26. Grafik Tegangan Terhadap kecepatan Motor DC

Dari data pada tabel 4 dapat dibuat grafik perbandingan antara sudut penyalaan terhadap putaran motor DC seperti pada Gambar 27.

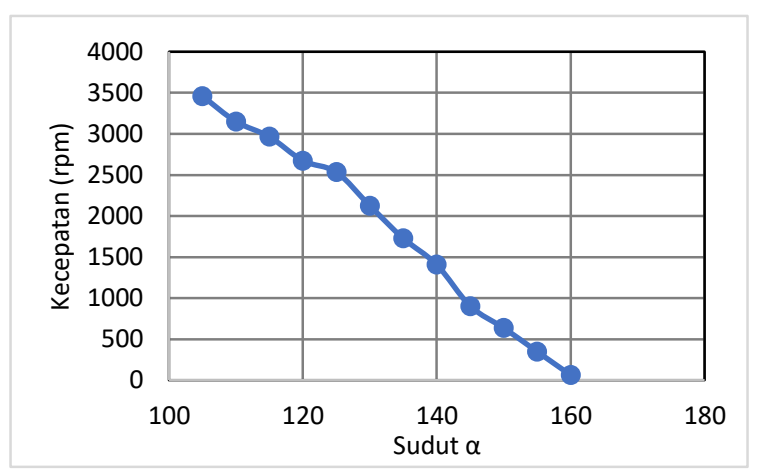

Gambar 27. Grafik Sudut $\alpha$ Terhadap Kecepatan Motor DC

Dari data pada Tabel 4 dapat dibuat grafik perbandingan antara arus rata-rata $\left(\mathrm{V}_{\mathrm{avg}}\right)$ terhadap putaran motor DC seperti pada Gambar 28.

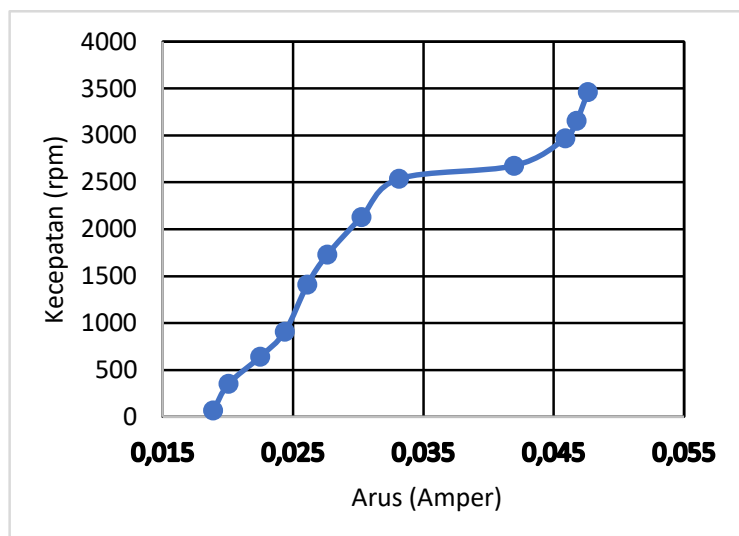

Gambar 28. Kecepatan Terhadap Arus 


\section{Sistem Kontrol Feedback}

Untuk mengontrol tegangan trigger, dapat dilakukan dengan mengatur tegangan kontrol $\left(\mathrm{V}_{11}\right)$ pada IC TCA785. Kemudian input tegangan kontrol tersebut dihubungkan ke pin output PWM pada arduino, untuk diagram blok dan system kontrol rangkaian seperti pada Gambar 29 dan Gambar 30.

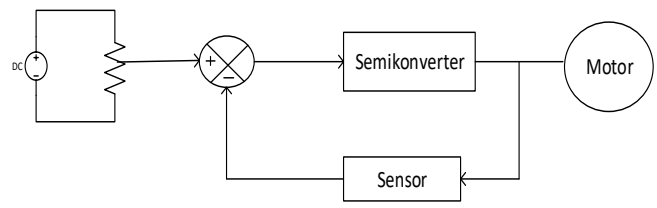

Gambar 29 Diagram Blok rangkaian

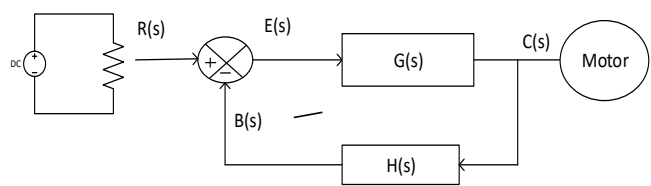

Gambar 30. Sistem Control feedback

Keterangan:

$\mathrm{R}(\mathrm{s})$ = Tegangan Refrensi

$\mathrm{E}(\mathrm{s})=$ Nilai eror

$\mathrm{G}(\mathrm{s})$ = Rangkaian

$\mathrm{H}(\mathrm{s})$ = Sensor Tegangan

$\mathrm{B}(\mathrm{s})$ = Tegangan feedback

$\mathrm{C}(\mathrm{s})$ = Tegangan Output

a. Tegangan eror beban induktansi pada E(s) adalah sebagai berikut :

$$
\begin{aligned}
& \mathrm{E}(\mathrm{s})=\mathrm{R}(\mathrm{s})-\mathrm{B}(\mathrm{s}) \\
& \mathrm{G}(\mathrm{s})=\frac{C(s)}{E(s)}
\end{aligned}
$$

b. Tegangan output $\mathrm{C}(\mathrm{s})$ beban induktansi rangkaian feedback

$$
\mathrm{C}(\mathrm{s})=\mathrm{G}(\mathrm{s}) \times \mathrm{E}(\mathrm{s})
$$

Tabel 5.

Hasil perhitungan E(s) dan G(s) seperti pada

Tabel 5. Hasil perhitungan beban induktif (Motor DC)

\begin{tabular}{cccc}
\hline No & $\mathrm{E}(\mathrm{s})$ & $\mathrm{G}(\mathrm{s})$ & $\mathrm{C}(\mathrm{s})$ \\
\hline 1 & $-0,001$ Volt & -17740 & 17,74 Volt \\
2 & 0,002 Volt & 6800 & 13,6 Volt \\
3 & 0,003 Volt & 3043,33 & 9,129 Volt \\
\hline
\end{tabular}

\section{KESIMPULAN}

1. Tegangan output semikonverter sudut $\alpha 105^{\circ}$ dengan beban resistor diperoleh tegangan $\mathrm{V}_{\text {rms }}$ semikonverter sebesar 121,57 Volt dan pada sudut penyalaan $160^{\circ}$ diperoleh tegangan $\mathrm{V}_{\text {rms }}$ sebesar 5,95 Volt dan semikonverter beban motor DC dengan sudut $\alpha 105^{\circ}$ diperoleh tegangan $\mathrm{V}_{\mathrm{rms}}$ semikonverter satu phasa sebesar 215,5 Volt dan sudut penyalaan $160^{\circ}$ diperoleh tegangan $V_{\text {rms }}$ sebesar 19,43 Volt.

2. Motor DC dengan tegangan suplai dari semikonverter satu phasa sebesar 215,5 Volt diperoleh kecepatan motor DC 3436 rpm dan tegangan suplai 19,43 Volt diperoleh kecepatan motor DC 74,6 rpm.

3. Semikonverter menggunakan feedback arduino dengan beban resistor diperoleh tegangan output sebesar 17,75 Volt dan beban motor sebesar 17,75 Volt

\section{DAFTAR PUSTAKA}

[1] M. Ashari, Disain Konverter Elektronika Daya. 2017.

[2] M. H. Rashid, Power Electronics Academic Press Series in Engineering. 2001.

[3] C. W. Lander, Power Electronics. England: McGRAW-HILL, 1993.

[4] D. Istradi, Pengenalan Elektronika Daya. 2017.

[5] Datasheet ACS712 from Allegro," https://s3.eucentral-1.amazonaws.com/aviracdn1.prod/ image/ipm/layout/av/logo.png.

[6] Features, datasheet IC TCA. pp. 1-16.

[7] K. A. W. Hudaya, A. Warsito, and M. Facta, Pembuatan Penyearah Terkontrol Penuh Satu Fasa Sebagai Pengemudi Motor Dc $3 \mathrm{Hp}$, Undergrad. thesis, Jur. Tek. Elektro Fak. Tek. Undip., pp. 1-6, 2002.

[8] Zuhal, Teknik Tenaga Listrik. Gramedia Pustaka Utama, jakarta, p. 252, 1998.

[9] Daryanto, konsep dasar teknik elektronika kelistrikan. 2016.

[10] A. Kadir, Pemrograman arduino dan processing. PT. Elex Media Komputindo, jakarta, 2017.

[11] R. Sulistyowati, D. D. Febriantoro, J. T. Elektro, and F. T. Industri, Perancangan Prototype Sistem Kontrol Dan Monitoring Pembatas Daya Listrik Berbasis, Vol. 16, 2012. 